\title{
Bactericidal Effects of Natural Tenderizing Enzymes on Escherichia Coli and Listeria monocytogenes
}

\author{
Hanan Eshamah ${ }^{1}$, Inyee Han ${ }^{1}$, Hesham Naas ${ }^{2}$, James Rieck ${ }^{3} \&$ Paul Dawson ${ }^{1}$ \\ ${ }^{1}$ Food, Nutrition and Packaging Sciences Department, Clemson University, Clemson, SC, USA \\ ${ }^{2}$ Department of Food Hygience, Faculty of Veterniary Medicine, University of Tripoli, Tripoli, Libya \\ ${ }^{3}$ Department of Mathematical Science, Clemson University, Clemson, SC, USA \\ Correspondence: Paul Dawson, Food, Nutrition and Packaging Science Department, Clemson University, \\ Clemson, SC 29624, USA. Tel: 1-864-656-1138. E-mail: pdawson@clemson.edu
}

Received: October 22, 2012 Accepted: November 2, 2012 Online Published: January 15, 2013

doi:10.5539/jfr.v2n1p8 URL: http://dx.doi.org/10.5539/jfr.v2n1p8

\begin{abstract}
The objective of this study was to determine the antimicrobial activity of proteolytic, meat-tenderizing enzymes (papain and bromelain) against E. coli and L. monocytogenes at three different temperatures $\left(5,25\right.$ and $\left.35^{\circ} \mathrm{C}\right)$. Two overnight cultures of $E$. coli JM109 and $L$. monocytogenes were separately suspended in $1 \%$ peptone water and exposed to a proteolytic enzyme (papain or bromelain) at three different temperatures. Bromelain concentrations $(4 \mathrm{mg} / \mathrm{ml})$ and $(1 \mathrm{mg} / \mathrm{ml})$ tested at $25^{\circ} \mathrm{C}$ against $E$. coli and L. monocytogenes, respectively, were the most effective concentrations tested reducing populations by 3.37 and $5.7 \log \mathrm{CFU} / \mathrm{ml}$ after $48 \mathrm{~h}$, respectively. Papain levels of $(0.0625 \mathrm{mg} / \mathrm{ml})$ and $(0.5 \mathrm{mg} / \mathrm{ml})$ were the most effective concentration tested at $25^{\circ} \mathrm{C}$ against $E$. coli and L. monocytogenes, respectively, reducing populations by 4.94 and $6.58 \log \mathrm{CFU} / \mathrm{ml}$ after $48 \mathrm{~h}$, respectively. Interestingly, the lower papain concentration tested $(0.0625 \mathrm{mg} / \mathrm{ml})$ was more effective than the higher concentration $(0.5 \mathrm{mg} / \mathrm{ml})$ against $E$. coli at all three temperatures. As expected, the temperature was directly related to enzyme efficacy against both $E$. coli and L. monocytogenes.
\end{abstract}

Keywords: proteolytic enzymes, bromelain, papain, meat tenderizing, Escherichia coli, Listeria monocytogenes

\section{Introduction}

Consumer acceptance or rejection for cut or processed meat after initial purchase is strongly influenced by tenderness. Meat tenderness is related to structural integrity of myofibrillar and connective tissues proteins (Marsh et al., 1966; Nishimura et al., 1995). Many studies have investigated methods to improve tenderness and overall meat quality using different tenderizing methods including: chemical tenderization of meat with enzymes, salts, or calcium chloride, and physical tenderization by pressure treatments, blade tenderization or electrical stimulation (Ketnawa \& Rawdkuen, 2011). Pathogenic bacteria are also a serious concern for consumers in further processed meat products. Gudbjomsdottir et al. (2004) reported the incidence of Listeria monocytogenes in meat processing plants was between 0 and $15 \%$ and in poultry plants was 20.6 to $24.1 \%$. A majority of food product recalls associated with $L$. monocytogenes contamination involve RTE meat and poultry products (USDA-FSIS, 2005). Lee et al. (2009) reported 9.1\% of beef, poultry and pork raw samples contained E. coli with 39 pathogenic isolates found among these isolates.

Plant proteolytic enzymes have also received attention in the field of medicine and biotechnology due to their proteolytic properties including papain from papaya (Carica papaya), bromelain from pineapple (Ananas comosus) and ficin from figs (Ficus spp.) (Ketnawa et al., 2010; Bhardwaj et al., 2012). These enzymes have been widely used in the food, medical-pharmaceutical, cosmetic and other industries. In the food industry, the primary application has been for meat tenderization.About $95 \%$ of tenderizing enzymes used for meat in the United States are from plant proteases. This marked tenderizing effect is due to the strong proteolytic activity of these enzymes (Amid et al., 2011).

Bromelain is mixture of proteolytic enzymes, many of which are cysteine proteases derived from the pineapple plant (Ananas comosus), which is a member of Bromeliaceae family (Hale et al., 2005). In the United States, bromelain is sold in health food stores as a nutritional supplement to promote digestive health and as an anti-inflammatory drug (Borrelli et al., 2011). Bromelain also has demonstrated antimicrobial effects including 
antihelminthic activity against gastrointestinal nematodes, anti-candida effects, and can resolve infectious skin diseases such as pityriasis lichenoides chronica (Bromelain Monograph, 2010). Corzo et al. (2012) reported that optimum $\mathrm{pH}$ and temperature conditions for proteolytic activity of bromelain are in range of $\mathrm{pH}$ 6.5-7.5 and $50-60^{\circ} \mathrm{C}$, respectively. Lopez-Garcia et al. (2006) reported that bromelain could be used as an alternative to chemical fungicides against Fusarium spp. plant pathogens. Salampessy et al. (2006) isolated antimicrobial peptides produced through bromelain hydrolysis of raw food.

Papain is another important plant peptidase derived from the latex of unripe papaya fruit (Carica papaya, Caricaceae) useful as a meat tenderizer due to its powerful proteolytic activity. Papain is characterized by its ability to hydrolyze large proteins into smaller peptides and amino acids. Its ability to break down tough fibers has been used for many years in the US as a natural tenderizing agent and is included as a component in meat tenderizers (Llerena-Suster, 2011).

Anibijuwon and Udeze (2009) concluded that Carica papaya maybe used for treatment of gastroenteritis, urethritis and wound infections. They also concluded that antimicrobial activity against both gram-negative and gram-positive bacteria is an indication that the Carica papaya is a potential source for production of a broad-spectrum bactericide. Moreover, Emeruwa (1982) supported that Carica papaya fruit extract had antibacterial activity against both gram-positive and gram-negative bacteria like E. coli and S. aureus. He also suggested that the site of action of the antibacterial was at cell wall since the cell morphology appeared to be changed. Raw papain extract was mixed with hydroxy methyl cellulose at a 1:2 ratio and tested against Enterococcus faecalis as a debriding gel for dentistry and showed $68 \%$ inhibition.

Ming et al. (2002) reported that optimum $\mathrm{pH}$ and temperature conditions for proteolytic activity of papain are in range of $\mathrm{pH} 6.0-7.0$ and $65-80^{\circ} \mathrm{C}$ respectively. While (Anibijuwon \& Udeze, 2009) said that the increase in temperature enhances the activity, whereas alkaline $\mathrm{pH}$ decreases the activity of papain. Meat consumption is increasing around the world and there are concerns related to the meat quality (tenderness) and meat. Meat tenderness can be addressed in different ways and meat hygiene concerns are mostly of a biological nature and include bacterial pathogens, such as Escherichia coli O157:H7, Salmonella and Campylobacter in raw meat and poultry, and Listeria monocytogenes in ready-to-eat processed products (Sofos et al., 2010). Since proteolytic enzymes are used in meat marinades and as meat tenderizers and these natural enzymes have displayed antimicrobial activity, they may have use in reducing pathogen risk in meat. Tests against common meat pathogens at temperatures used to hold and store meat seem appropriate. Therefore, the objective of this study was to examine two proteolytic enzymes (bromelain and papain) for antimicrobial activity against E.coli and L.monocytogenes when held at different temperatures $\left(5,25\right.$ and $\left.35^{\circ} \mathrm{C}\right)$.

\section{Method}

\subsection{Inoculum Preparation}

Ampicillin-resistant E.coli $J M 109$ was preserved by freezing the culture at $-70^{\circ} \mathrm{C}$ in vials containing tryptic soy broth (Becto ${ }^{\mathrm{TM}}$ Tryptic Soy Broth, Becton Dickinson and company Sparks, MD 21152 USA) supplemented with $20 \%$ ( $\mathrm{v} / \mathrm{v}$ ) glycerol (Sigma, St. Louis, MO). To propagate the culture, a frozen vial was thawed at room temperature, and $0.1 \mathrm{ml}$ of the thawed culture was transferred to $9.9 \mathrm{ml}$ of Enrichment TSB with $0.5 \%$ ampicillin (DIFCO) in screw-capped tubes and incubated aerobically for $16-18 \mathrm{~h}$ at $37^{\circ} \mathrm{C}$ with shaking (Thermolyne Maxi-Mix III type 65800, Barnstead/ Thermolyne, Dubuque, IA). The inoculum was prepared from a second transfer of this culture $(0.1 \mathrm{ml})$ to another $9.9 \mathrm{ml}$ tube of Enrichment TSB (DIFCO), and incubated aerobically for $16-18 \mathrm{~h}$ at $37^{\circ} \mathrm{C}$ with shaking. After overnight incubation, washed cells were harvested by centrifugation at $1107 \times \mathrm{g}($ IEC HN-SII Centrifuge, International Equipment CO., Inc., Needham Heights, MA), the pellet resuspended in sterile peptone water $0.1 \%$ (w/v) (Bacto peptone, Becton Dickinson) to obtain a population of approximately 8-9 $\log \mathrm{CFU} / \mathrm{ml}$. One $\mathrm{ml}$ of the suspension was transferred into $99 \mathrm{ml}$ of sterile peptone water $0.1 \%$ $(\mathrm{w} / \mathrm{v})$ to obtain a final population of approximately 5-6 $\log \mathrm{CFU} / \mathrm{ml}$. Initial cell populations were verified by enumeration of the cells following pour-plating in TSA with $0.5 \%$ ampicillin (DIFCO ${ }^{\mathrm{TM}}$ Tryptic Soy Agar, Becton Dickinson and company Sparks, MD 21152 USA) and incubating at $37^{\circ} \mathrm{C}$ for $24 \mathrm{~h}$. The same procedure was followed with Listeria monocytogenes (ATCC 15313) grown in Listeria broth (DIFCO ${ }^{\mathrm{TM}}$ Listeria Enrichment broth, Becton Dickinson and Company Sparks, MD 21152 USA).

\subsection{Preparation of Enzyme Concentrations}

The concentrations of bromelain (B4882-25G, sigma) used with L.monocytogenes were $0 \mathrm{mg} / \mathrm{ml}, 0.25 \mathrm{mg} / \mathrm{ml}$, $0.375 \mathrm{mg} / \mathrm{ml}$ and $1.0 \mathrm{mg} / \mathrm{ml}$ while for $E$. coli, $0 \mathrm{mg} / \mathrm{ml}, 1.0 \mathrm{mg} / \mathrm{ml}, 2.0 \mathrm{mg} / \mathrm{ml}$ and $4.0 \mathrm{mg} / \mathrm{ml}$ were used based on preliminary experiments. These concentrations were prepared by mixing appropriate amount of the peptone solution, enzyme stock solution and bacterial solution. The same procedure was followed with papain 
(P4762-500MG) using different concentrations. For example, concentrations of papain with E.coli and $L$. monocytogenes were $0 \mathrm{mg} / \mathrm{ml}, 0.0625 \mathrm{mg} / \mathrm{ml}, 0.125 \mathrm{mg} / \mathrm{ml}, 0.25 \mathrm{mg} / \mathrm{ml}$, and $0.5 \mathrm{mg} / \mathrm{ml}$.

Enzyme and peptone solution of the different concentrations were mixed for $30 \mathrm{sec}$. until a homogenized solution was achieved. At $\mathrm{t}=0 \mathrm{~h}$ the bacteria was added to the different mixtures and finally transferred to sterile petri dishes and placed on an orbit shaker at $40 \mathrm{rpm}$ (Model 3520 Orbit shaker, Lab-Line Instruments, Inc) at different temperatures $5,25,35^{\circ} \mathrm{C}$.

\subsection{Sampling Time}

At $\mathrm{t}=0,2,4,8,24$, and $48 \mathrm{~h}, 0.1 \mathrm{ml}$ of each enzyme concentration were serially diluted and appropriate serial dilutions were surface plated on enrichment agar, Listeria agar (DIFCO Detroit, MI) for L. monocytogenes and TSA (DIFCO, Detroit, MI) for E. coli, in duplicate.

The inoculated plates were incubated (Model $2300 \mathrm{CO}_{2}$ incubator, VWR Scientific Product) at $37^{\circ} \mathrm{C}$ for $48 \mathrm{~h}$ for $L$. monocytogenes and $24 \mathrm{~h}$ for $E$. coli and dilution plates with 25-250 colonies were counted (LEICA, QUEBEC DARK FIELD colony counter, Buffalo, NY 14240 USA model 3325) and populations were reported a CFU/ml and $\log \mathrm{CFU} / \mathrm{ml}$.

\subsection{Statistical Analysis}

The experiment was conducted as a repeated measures split-plot experimental design. The response variable was logarithmic function of the colony forming units (log CFU) per ml. The whole-plot treatment factor was enzyme concentration and sub-plot treatment factor was temperature. Measurements were repeated over time $(0,2,4,8$, 24 and $48 \mathrm{~h}$ ) the covariance matrix was modeled using spatial power law that is a generalization of the first-order autoregressive covariance structure. The PROC MIXED procedure from $\mathrm{SAS}^{\circledR}$ was used to analyze the data and the Tukey multiple comparison procedure was for mean separation. All comparisons were made using $\alpha=0.05$.

\section{Results}

\subsection{Bromelain}

\subsubsection{Effect of Bromelain on E. coli}

Bromelain was tested at concentrations from 1 to $4 \mathrm{mg} / \mathrm{ml}$ at 5,25 , and $35^{\circ} \mathrm{C}$ and was effective at all concentrations in reducing bacterial populations after 24 and $48 \mathrm{~h}$ compared to no added bromelain $(\mathrm{P} \leq 0.0001)$ (Figure 1). However, there was not a difference $(\mathrm{P}>0.05)$ in $E$. coli populations among samples exposed to bromelain concentrations of 1,2 or $4 \mathrm{mg} / \mathrm{ml}$ at 5 and $25^{\circ} \mathrm{C}$. At $48 \mathrm{~h}$, a bromelain concentration of $4 \mathrm{mg} / \mathrm{ml}$ was the most efficient on $E$. coli reducing the $\log \mathrm{CFU} / \mathrm{ml}$ population by $5.5(\mathrm{P}<0.0001)$. Similar results were observed by Sparso and Moller (2002) who added bromelain to soy protein films to inhibit E. coli. The exact mechanism by which bromelain inhibits the growth of $E$. coli is not completely understood but could be related to compromise of the Gram-negative outer membrane which also contains proteins. These surface proteins may be digestible by bromelain, weakening the cell wall to allow leakage, swelling of the cell and finally cell fracture. 


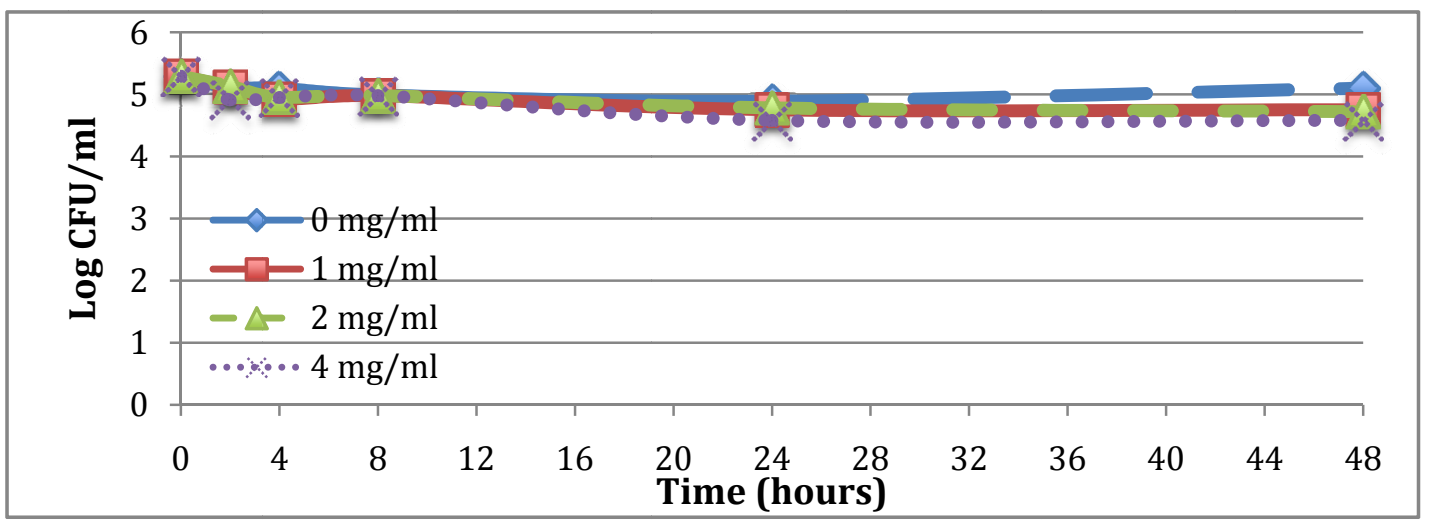

1a. Bromelain against $E$. coli at $5^{\circ} \mathrm{C}$

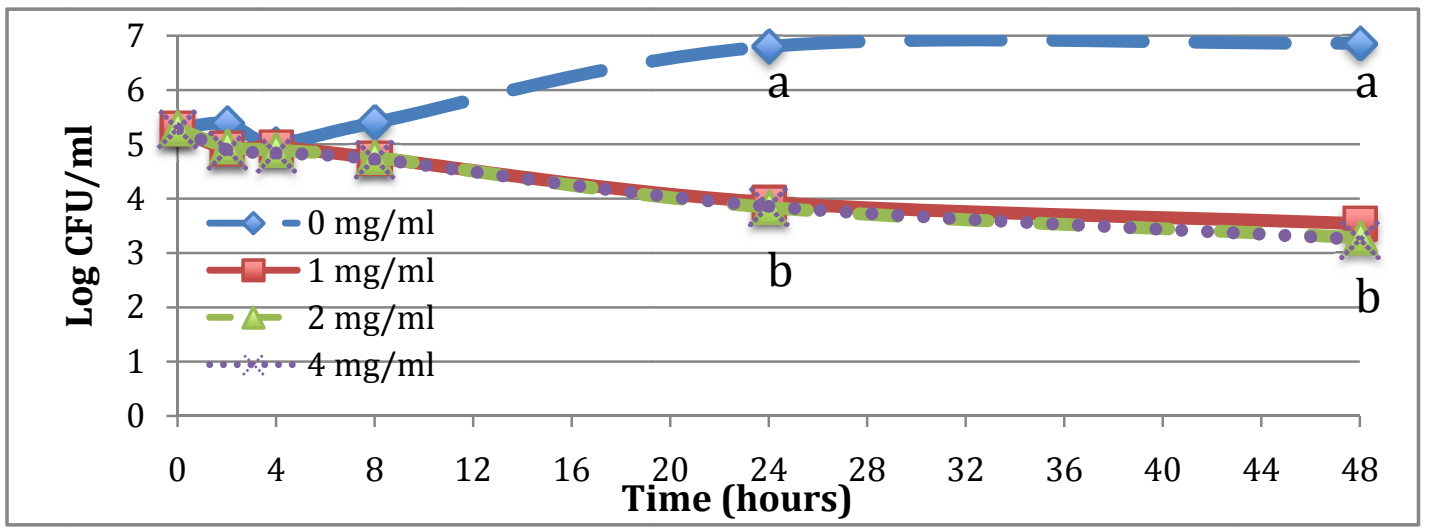

1b. Bromelain against $E$. coli at $25^{\circ} \mathrm{C}$

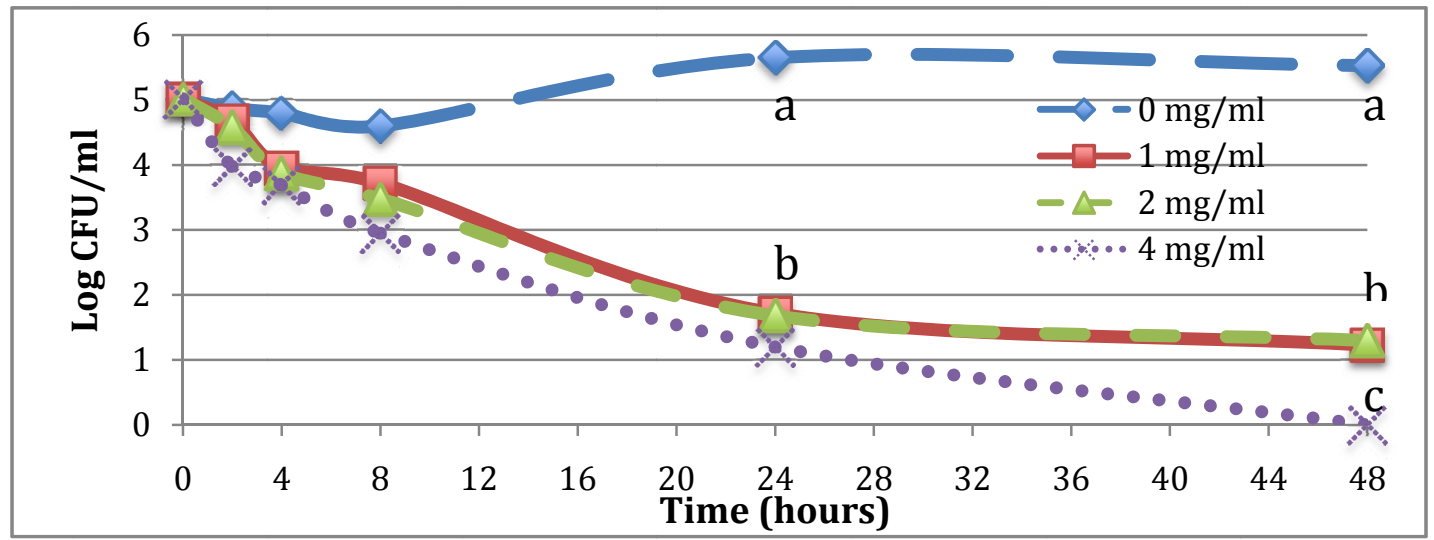

1c. Bromelain against E. coli at $35^{\circ} \mathrm{C}$

Figure 1. Effect of bromelain on E. coli at 5,25 and $35^{\circ} \mathrm{C}$ over 48 hours

$\mathrm{a}, \mathrm{b}, \mathrm{c}$ data points or groups of points with the same superscripts are not significantly different $(\mathrm{p}>0.05)$. Standard error of the mean $=0.18$.

\subsubsection{Effect of Bromelain on L. monocytogenes}

Bromelain reduced L. monocytogenes populations after $4 \mathrm{~h}$ for all 3 temperatures tested $(\mathrm{P}<0.0001)$ (Figure 2) however, there was not a difference in populations at concentrations of 0.25 and $0.375 \mathrm{mg} / \mathrm{ml}$ after $4 \mathrm{~h}$. After 2 and $4 \mathrm{~h}$ at $35^{\circ} \mathrm{C}$, the $1 \mathrm{mg} / \mathrm{ml}$ bromelain level reduced L. monocytogenes by $3 \log$ cycles which was significantly greater than the other concentrations tested. After $8 \mathrm{~h}$, L. monocytogenes population exposed to $1 \mathrm{mg} / \mathrm{ml}$ was significantly lower compared to bacteria exposed to concentrations of 0.25 and $0.375 \mathrm{mg} / \mathrm{ml}$ at all temperatures tested. This finding contradicts Sparso and Moller (2002) who concluded that bromelain is more efficient against 
Gram-negative than Gram-positive bacteria. Overall, bromelain at the $1 \mathrm{mg} / \mathrm{ml}$ level was more effective in reducing L. monocytogenes populations than all other levels tested $(\mathrm{P}<0.0001)$.

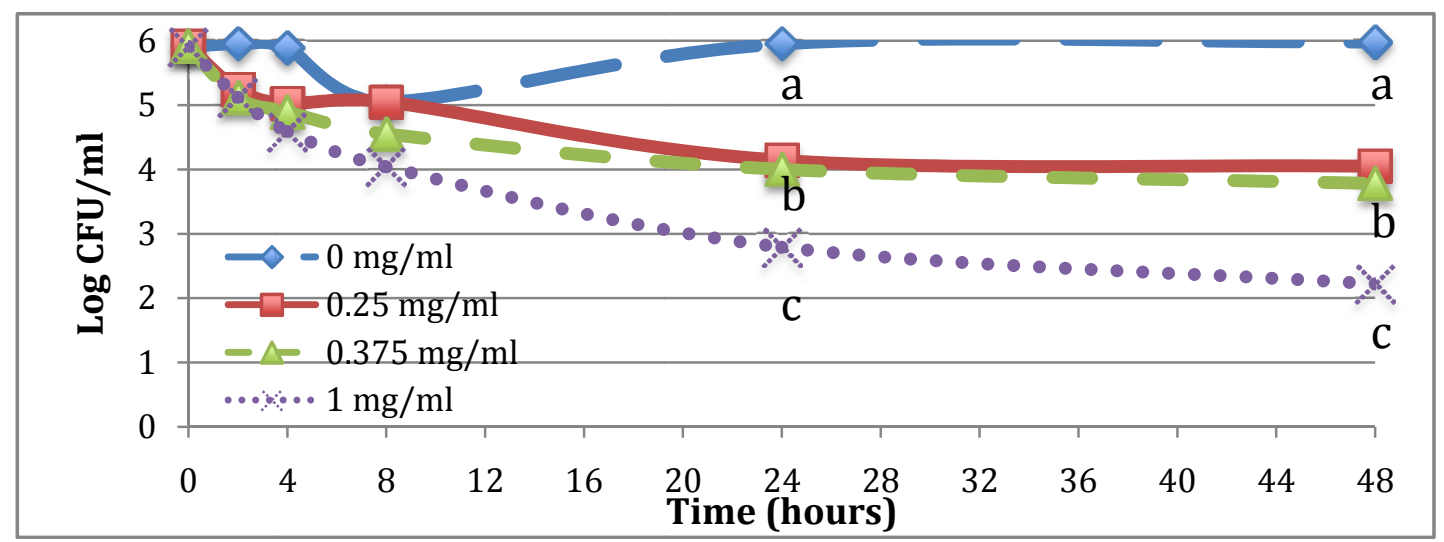

2a. Bromelain against L. monocytogenes at $5^{\circ} \mathrm{C}$

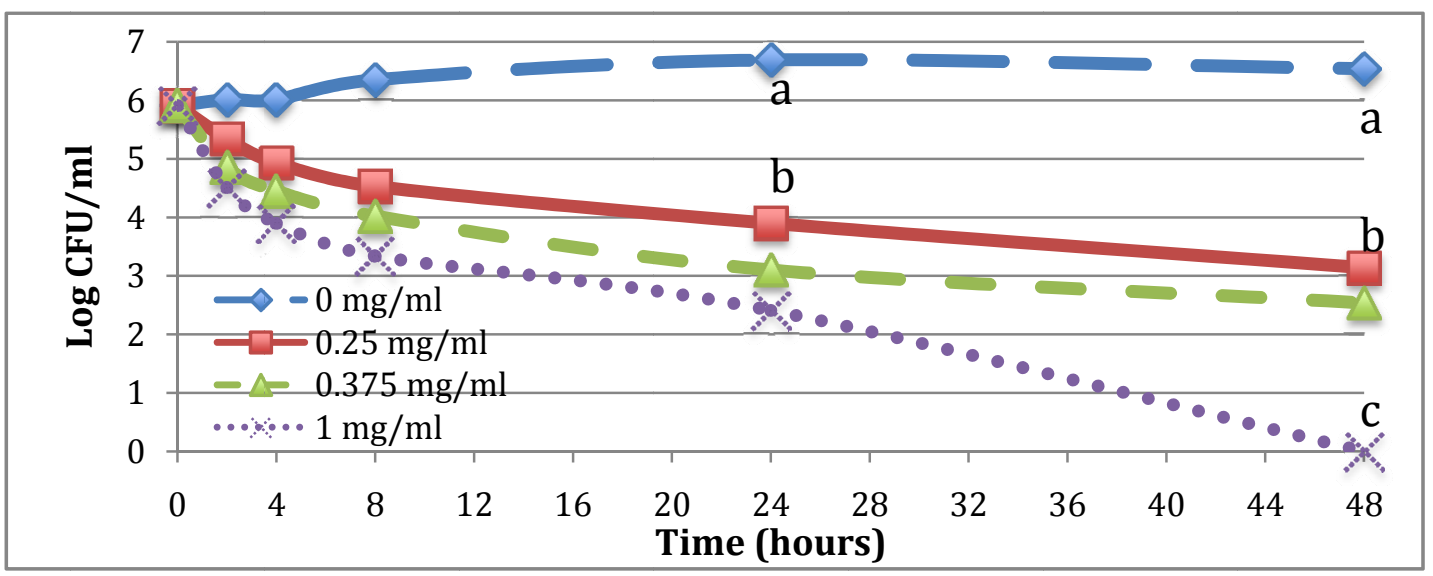

2b. Bromelain against L. monocytogenes at $25^{\circ} \mathrm{C}$

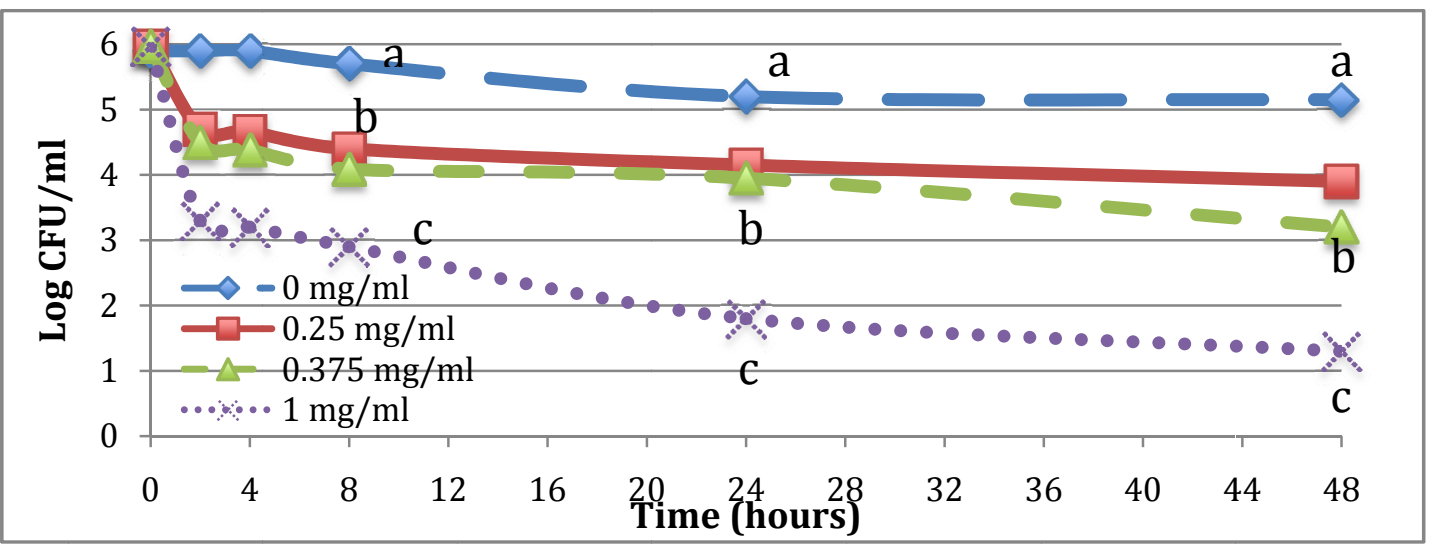

2c. Bromelain against L. monocytogenes at $35^{\circ} \mathrm{C}$

Figure 2. Effect of bromelain on L.monocytogenes at at 5,25 and $35^{\circ} \mathrm{C}$ over $48 \mathrm{~h}$

$\mathrm{a}, \mathrm{b}$, cdata points or groups of points with the same superscripts are not significantly different $(\mathrm{p}>0.05)$. Standard error of the mean $=0.24$.

\subsubsection{Effect of Temperature on Bromelain Efficiency}

The 48 hours exposure time was used as a comparison point for the temperature effects of the enzymes on bacteria. As temperature increased from 5 to $35^{\circ} \mathrm{C}$, the efficacy of bromelain to reduce both $E$. coli and $L$. monocytogenes increased (Figures 3 and 4). The optimum temperature conditions for proteolytic activity of 
bromelain are in range of $50-60^{\circ} \mathrm{C}$. (Corzo et al., 2012) thus as this optimum temperature was approached the greater activity yielded greater cell destruction. At $5^{\circ} \mathrm{C}$, bromelain had no effect on $E$. coli populations after 24 hours at all concentrations tested. However at $25^{\circ} \mathrm{C}$, bromelain concentrations were reduced at least $3 \log$ cycles after $24 \mathrm{~h}$ at all concentrations. At $25^{\circ} \mathrm{C}$, E. coli populations were reduced by $5 \log$ cycles using $1 \mathrm{mg} / \mathrm{ml}$ and by 6 $\operatorname{logs}$ (below detection) at $4 \mathrm{mg} / \mathrm{ml}$. The effect of increasing temperature and increasing activity against $E$. coli by bromelain was not observed against L. monocytogenes (Figure 4). Bromelain reduced L. monocytogenes by $1 \log$ cycle at 0.25 and $0.4 \mathrm{mg} / \mathrm{ml}$ and by $3 \operatorname{logs}$ at $4.0 \mathrm{mg} / \mathrm{ml}$ after 24 hours at $5^{\circ} \mathrm{C}$. These reductions were only $1-1.5 \operatorname{logs}$ greater at 25 and $35^{\circ} \mathrm{C}$, respectively after 24 hours for bromelain against L. monocytogenes.

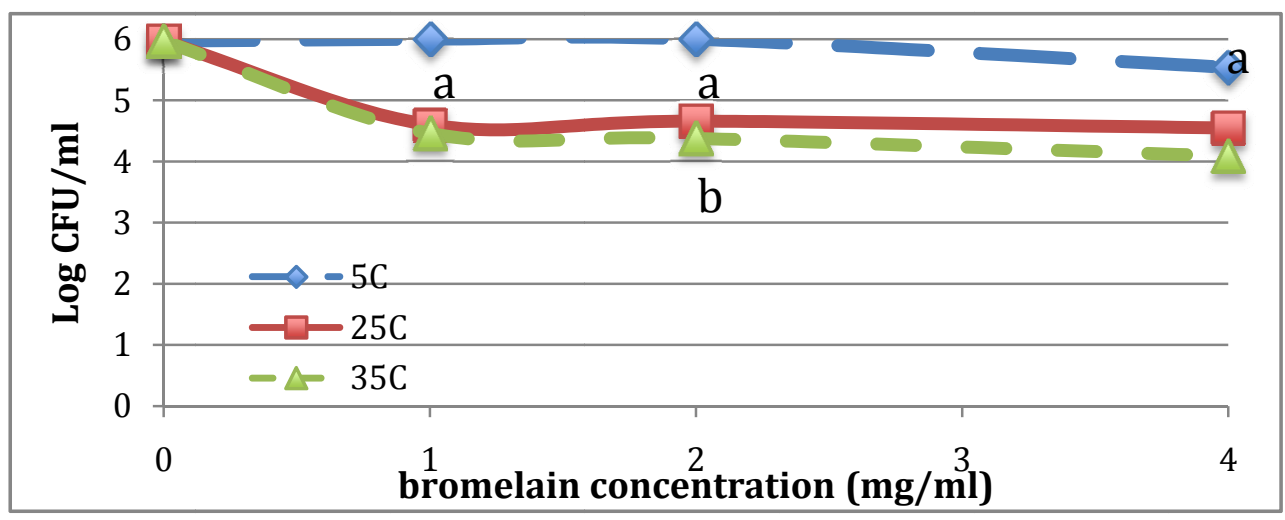

Figure 3. Effect of temperature on bromelain efficiency against on E. coli after $48 \mathrm{~h}$

$\mathrm{a}, \mathrm{b}, \mathrm{c}$ data points or groups of points with the same superscripts are not significantly different $(\mathrm{p}>0.05)$. Standard error of the mean $=0.25$.

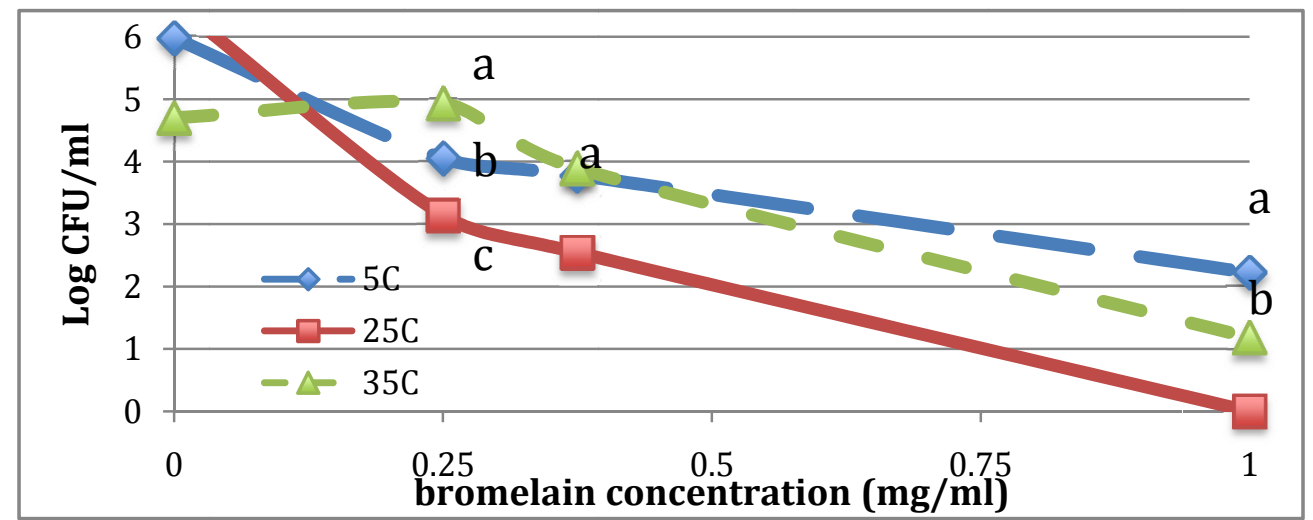

Figure 4. Effect of temperature on bromelain efficiency against L. monocytogenes after $48 \mathrm{~h}$

$a, b, c$ data points or groups of points with the same superscripts are not significantly different $(p>0.05)$. Standard error of the mean $=0.24$.

\subsection{Papain}

\subsubsection{Effect of Papain on E. coli}

Papain was tested in concentrations from 0.0625 to $0.5 \mathrm{mg} / \mathrm{ml}$ at 5,25 and $35^{\circ} \mathrm{C}$ with all concentration reducing E. coli populations significantly compered to the control (no papain). At room temperature $\left(25^{\circ} \mathrm{C}\right)$, the lower papain concentration of $0.0625 \mathrm{mg} / \mathrm{ml}$ was the most efficient on E. coli (Figure 6b). It reduced the $\log$ of $\mathrm{CFU} / \mathrm{ml}$ by $4.94(\mathrm{P}<0.0001)$, while the higher papain concentration of $0.5 \mathrm{mg} / \mathrm{ml}$ was the less effective. At $5^{\circ} \mathrm{C}$ the activity of papain against $E$. coli was reduced only yielding a 1-log reduction compared to the control except for the lowest concentration $(0.0625 \mathrm{mg} / \mathrm{ml})$ that showed nearly a $2.5 \log$ reduction after $48 \mathrm{~h}$. The most significant reduction in $E$. coli population with papain was at $35^{\circ} \mathrm{C}$ where all concentration reduced populations below detection after $48 \mathrm{~h}$ while the $0.0625 \mathrm{mg} / \mathrm{ml}$ level achieved this in 24 hours while other concentrations 
lagged behind this rate. Papain did not have any effect on E. coli at $35^{\circ} \mathrm{C}$ (Figure 5) until $4 \mathrm{~h}$ and the lower papain concentration $(0.0625 \mathrm{mg} / \mathrm{ml})$ was most effective. The antibacterial effect of papain found in this study is similar to those of Sparso and Moller (2002) where L. plantarum was significantly reduced by lower concentrations of papain. They explained that the relatively high concentration of protein in enzymes might inhibit or even destroy the enzyme because of the proteolytic properties.

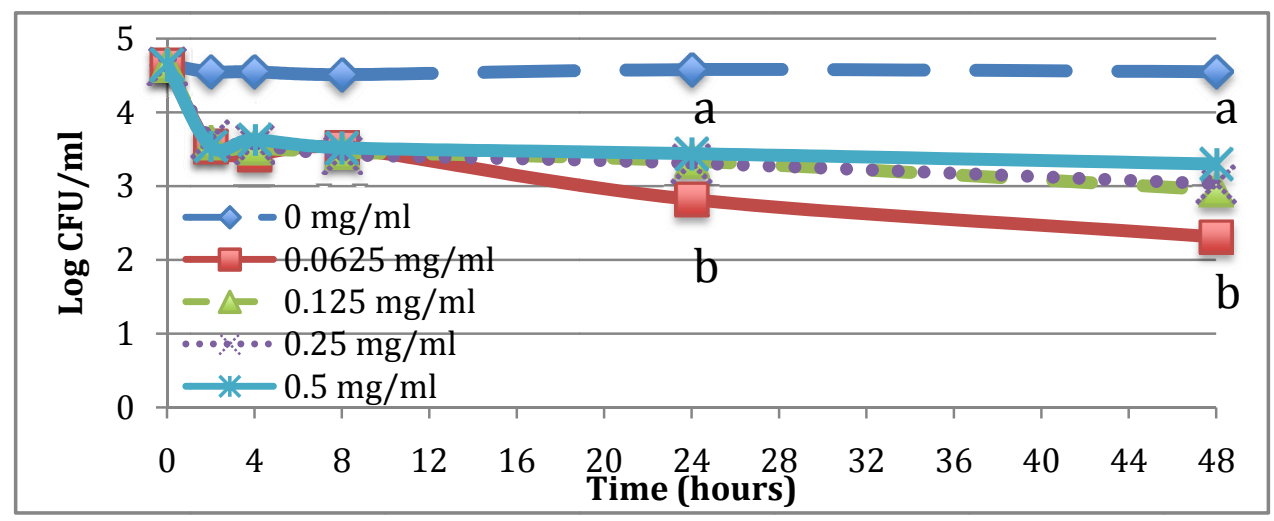

5a. Papain against $E$. coli at $5^{\circ} \mathrm{C}$

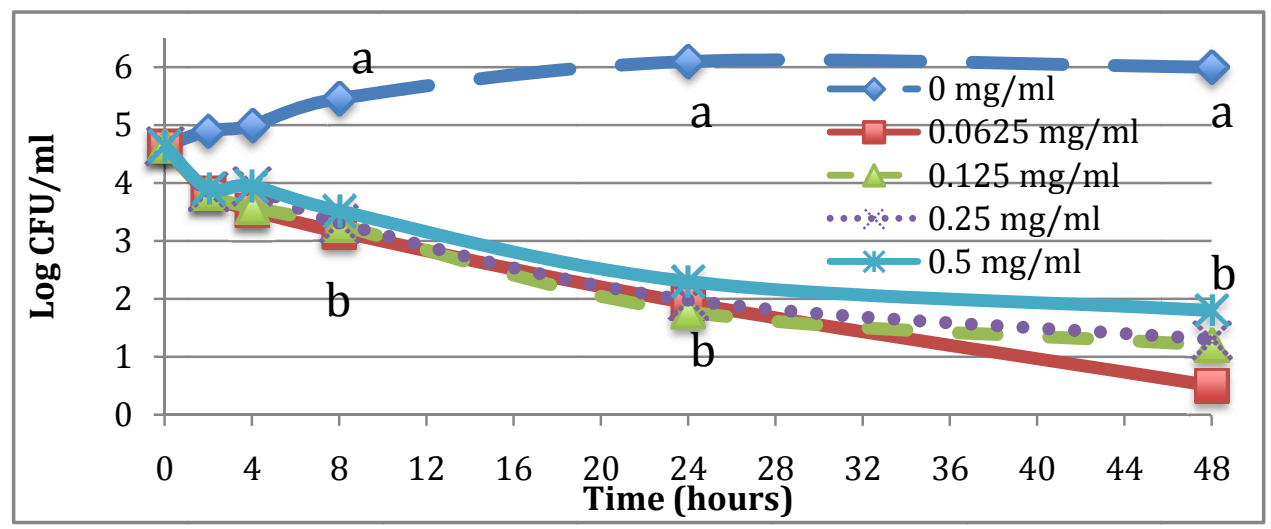

5b. Papain against $E$. coli at $25^{\circ} \mathrm{C}$

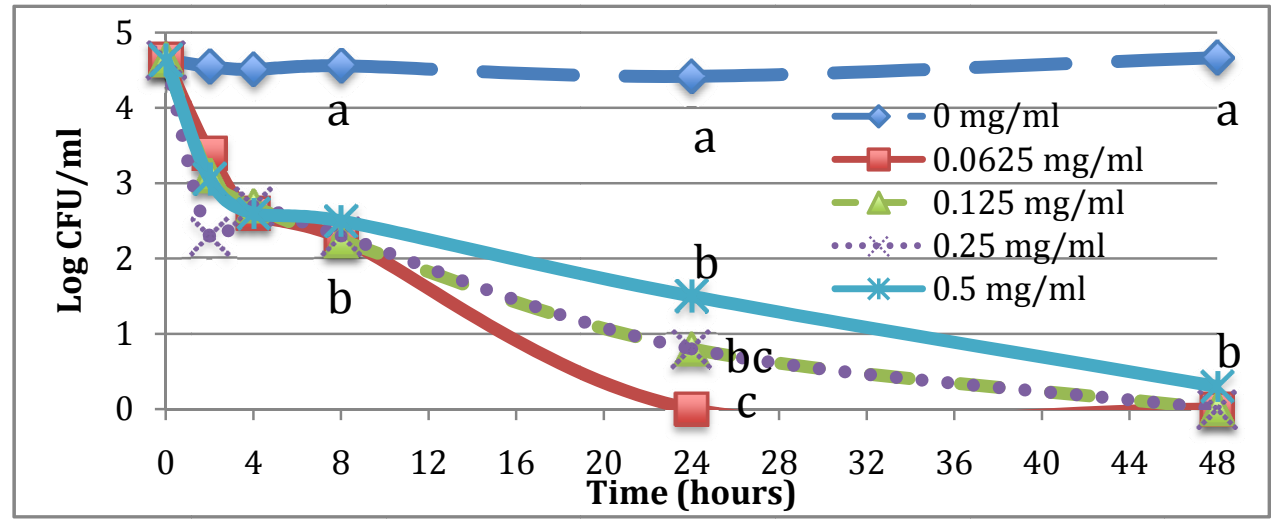

5.c. Papain against E. coli at $35^{\circ} \mathrm{C}$

Figure 5. Effect of papain on E. coli at 5,25 and $35^{\circ} \mathrm{C}$

$\mathrm{a}, \mathrm{b}, \mathrm{c}$ data points or groups of points with the same superscripts are not significantly different $(\mathrm{p}>0.05)$. Standard error of the mean $=0.46$.

\subsubsection{Effects of Papain on L. monocytogenes}

At $5^{\circ} \mathrm{C}$ papain slowly reduced L. monocytogenes populations at all concentrations tested yielding about a 2-log 
cycle reduction after $48 \mathrm{~h}$ compared to controls (Figure 6a). Papain concentrations of 0.0625 to $0.5 \mathrm{mg} / \mathrm{ml}$ at room temperature $\left(25^{\circ} \mathrm{C}\right)$ reduced L. monocytogenes population by $2 \log$ cycles after $8 \mathrm{~h}$ and 4 to $6 \operatorname{logs}$ after 24 and $48 \mathrm{~h}$, respectively, (Figure 6b) compared to the control $0 \mathrm{mg} / \mathrm{ml}$, which increased in population (log 0.44 $\mathrm{CFU} / \mathrm{ml}$ ) after $48 \mathrm{~h}$. At $35^{\circ} \mathrm{C}$, the rate of L. monocytogenes inactivation was greatest reaching a $4.5-$ to $5-\log$ reduction in $8 \mathrm{~h}$ and complete elimination of detectable cells by $24 \mathrm{~h}$. All papain concentrations were equally effective in reducing L. monocytogenes with the $0.5 \mathrm{mg} / \mathrm{ml}$ level significantly reducing bacterial numbers after $24 \mathrm{~h}$ at $5^{\circ} \mathrm{C}$ and $8 \mathrm{~h}$ at $35^{\circ} \mathrm{C}$ compared to the $0.0625 \mathrm{mg} / \mathrm{ml}$ concentration. The antibacterial effect of papain would be similar to bromelain and was theorized to inhibit bacterial cell wall synthesis or general protein synthesis (Osato et al., 1993).

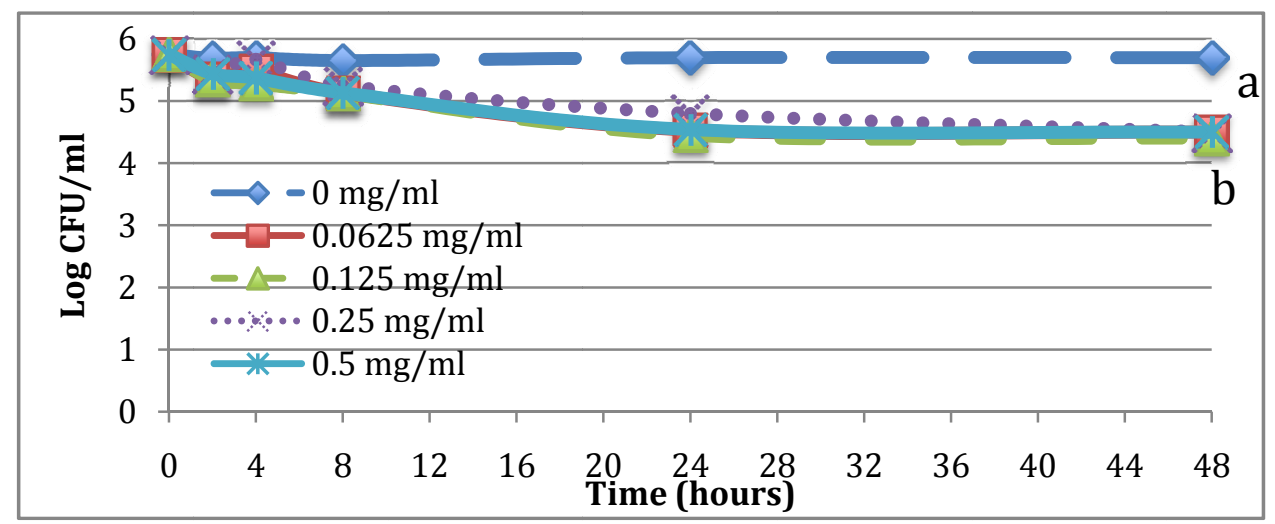

6a. Papain against L. monocytognes at $5^{\circ} \mathrm{C}$

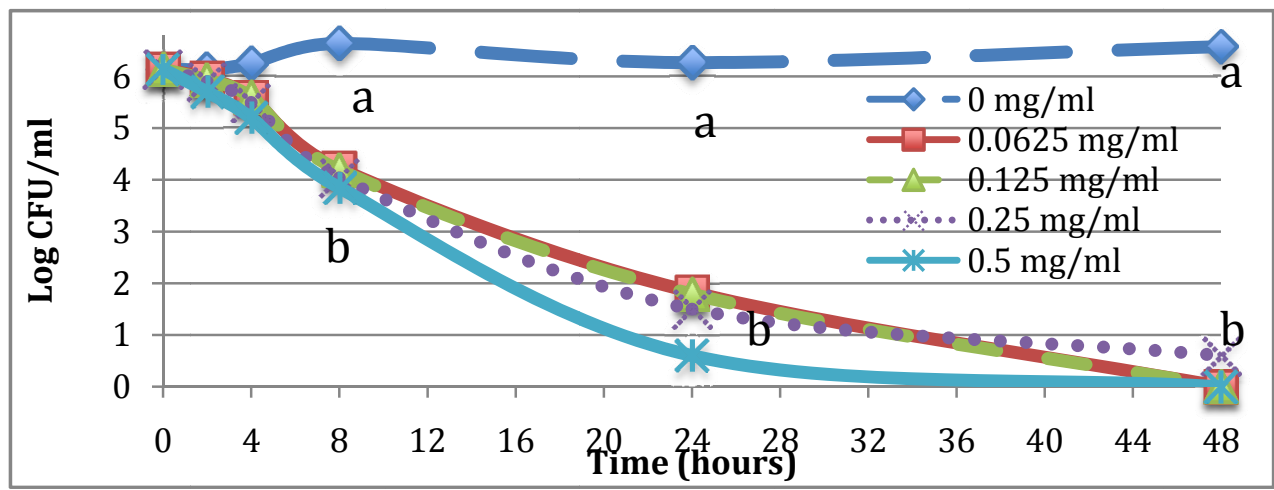

6b. Papain against L. monocytogenes at $25^{\circ} \mathrm{C}$

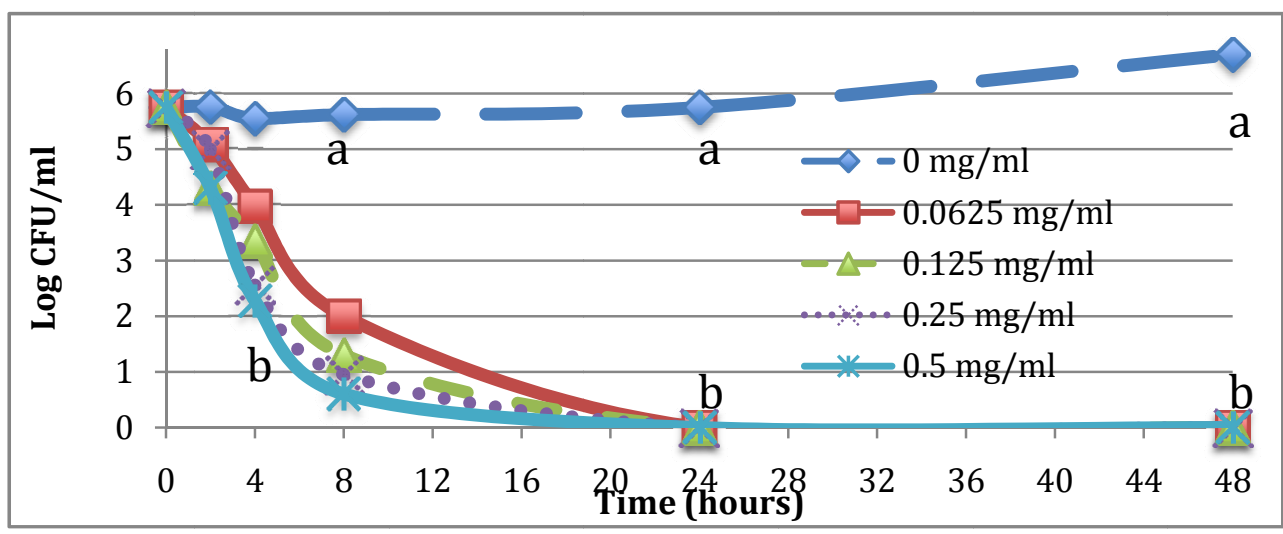

6c. Papain against L. monocytogenes at $35^{\circ} \mathrm{C}$

Figure 6. Effect of papain on L.monocytogenes at 5,25 , and $35^{\circ} \mathrm{C}$

a, b, c data points or groups of points with the same superscripts are not significantly different $(p>0.05)$. Standard error of the mean $=0.26$. 


\subsubsection{Effect of Temperature on Papain Efficiency}

There was no difference in the effect of papain concentration $(0.0625,0.125,0.25$ and $0.5 \mathrm{mg} / \mathrm{ml})$ on $E$. coli population after $24 \mathrm{~h} \mathrm{at} 5^{\circ} \mathrm{C}$ (Figure 7). However, all papain concentrations reduced L. monocytogenes population after $24 \mathrm{~h}$ at $5^{\circ} \mathrm{C}$ compared to controls. At $25^{\circ} \mathrm{C}$, there was at least a 3-log reduction of E. coli and a 4-log reduction of L. monocytogenes at all concentrations tested compared to controls (Figure 8). The 24-hour reduction in E. coli held at $25^{\circ} \mathrm{C}$ and $35^{\circ} \mathrm{C}$ did not differ among the concentrations tested. However for $L$. monocytogenes, the $25^{\circ} \mathrm{C}$ was about 1 -log higher in populations after 24 hours than the $35^{\circ} \mathrm{C}$ treatment at each concentration.

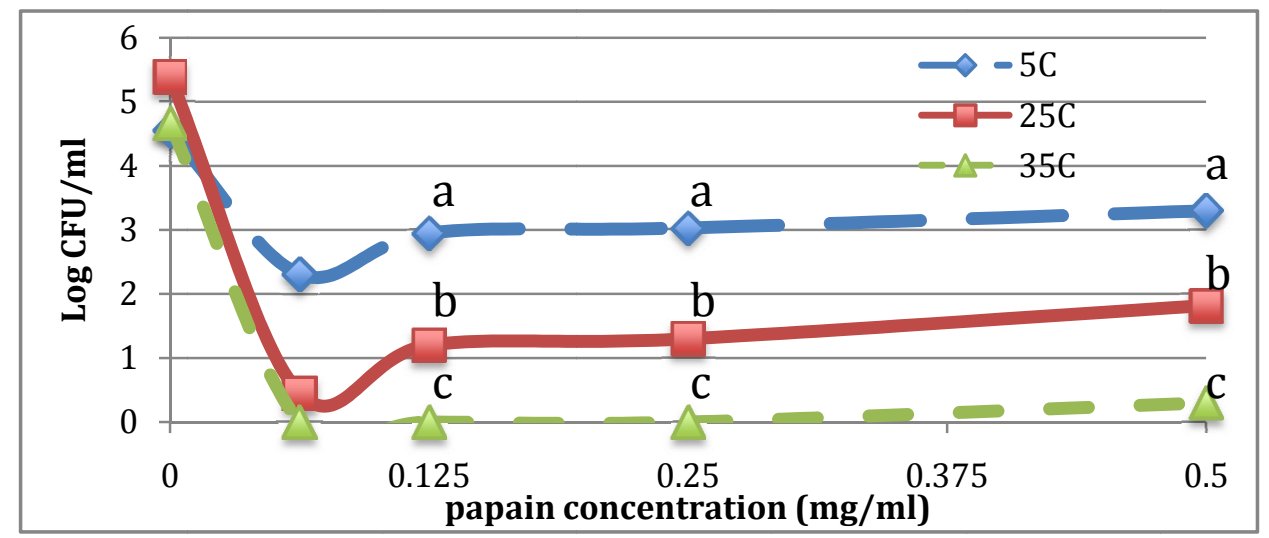

Figure 7. Temperature effect of papain on E. coli after $48 \mathrm{~h}$

$\mathrm{a}, \mathrm{b}, \mathrm{c}$ data points or groups of points with the same superscripts are not significantly different $(\mathrm{p}>0.05)$. Standard error of the mean $=0.23$.

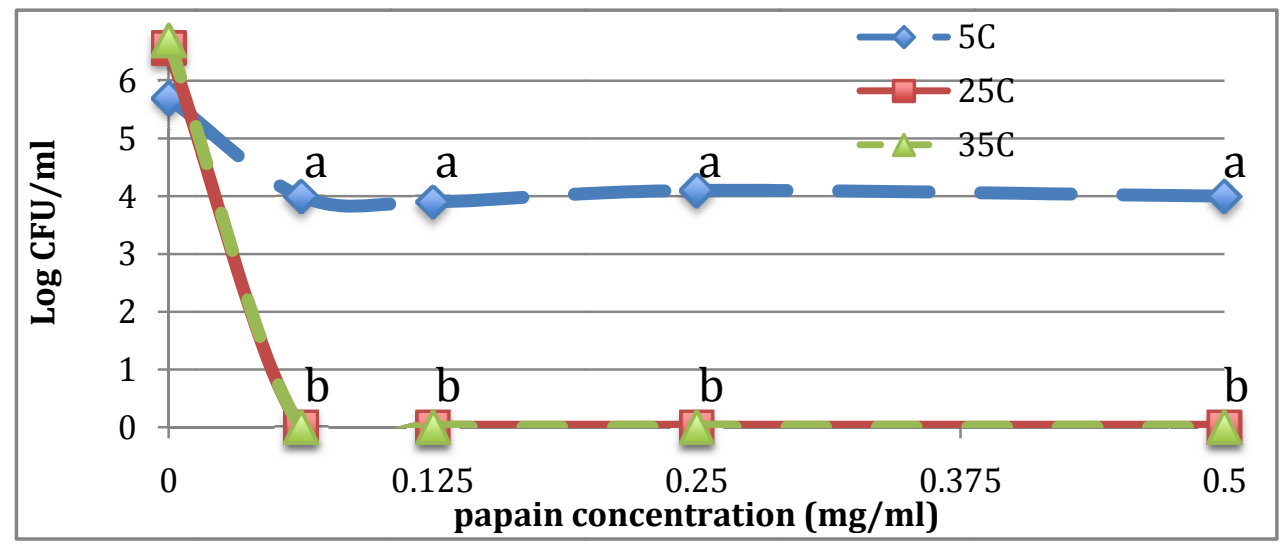

Figure 8. Effect of temperature of papain on L. monocytogenes after $48 \mathrm{~h}$

$a, b, c$ data points or groups of points with the same superscripts are not significantly different $(p>0.05)$. Standard error of the mean $=0.35$.

\section{Discussion}

In general, all enzyme treatments were most effective at $35^{\circ} \mathrm{C}$. However, $25^{\circ} \mathrm{C}$ and $35^{\circ} \mathrm{C}$ did not differ forpapain but did differ in antimicrobial activity of bromelain.Temperature effects on enzyme activity was demonstrated by Ming et al. (2002) as the optimum temperature conditions for proteolytic activity of bromelain and papain are in range of $50-60^{\circ} \mathrm{C}$ and $65-80^{\circ} \mathrm{C}$, respectively. Moreover, Anibijuwon and Udeze, 2009 reported that the increase in temperature enhances papain activity. Both bromelain and papain belong to a family of cysteine proteases that are activated by cysteine, which is located at the active site of the enzyme. Bromelain preferentially cleavesat amino acid sites involving lysine, alanine, tyrosine and glycine while papain prefers hydrophobic sites that include valine and also lysine. The enzyme breaks bonds at selected locations dividing the protein chain into fragments. 
Gram-negative bacterial cell walls differ from Gram-positive cell walls containing an outer membrane comprised of protein, lipoprotein and lipopolysaccharides, a peptidoglycan layer then a plasma membrane that also contains proteins. Gram-positive bacteria have a thick peptidoglycan layer and an inner plasma membrane. The surface layer of both Gram positive and Gram-negative bacteria contain protein components that can be targeted by proteases to compromise cell wall structure to varying degrees. For example, the peptidoglycan layer (outer layer of Gram-positive bacteria) consists of subunits that are joined by crosslinks between the amino group of one amino acid and the carboxyl group of alanine (Prescott et al., 1990), a preferred scission site for bromelain. In contrast, Gram-negative bacteria have an outer lipopolysaccharide layer that contains porin proteins that a lined with exclusively charged amino acids to facilitate passage of molecules through the membrane (Schirmer, 1998); papain prefers uncharged (hydrophobic) amino acid sites. The different responses observed to bromelain and papain for E. coli and L. monocytogenes are likely to be due, in part to the differences in cell wall/membrane structure amino acid presence between Gram-negative $(E$. coli) and Gram-positive (L. monocytogenes). The presence and availability of amino acids in bacterial cell wall proteins that are enzyme targets will enhance or inhibit protease antibacterial activity. The antimicrobial activity of proteolytic enzymes used as meat-tenderizing agents reported here and in other sources may enhance the safety and shelf life of marinated meat products.

\section{References}

Amid, A., Ismail, N. A., Yusof, F., \& Salleh, H. M. (2011). Expression, purification, and characterization of a recombinant stem bromelain from ananas comosus. Process Biochemistry, 46(12), 2232-2239. http://dx.doi.org/10.1016/j.procbio.2011.08.018

Anibijuwon, I. I., \& Udeze, A. O. (2009). Antimicrobial Activity of Carica Papaya (Pawpaw Leaf) on Some Pathogenic Organisms of Clinical Origin from South-Western Nigeria. Ethnobotanical leaftels, 13, 850-64.

Bhardwaj A., Ballal S., \& Velmurugan, N. (2012). Comparative evaluation of the antimicrobial activity of natural extracts of Morinda citrifolia, papain and aloe vera (all in gel formulation), $2 \%$ chlorhexidine gel and calcium hydroxide, against Enterococcus faecalis: An in vitro study. Journal of Conservative Dentistry, 15, 293-297. http://dx.doi.org/10.4103/0972-0707.97964

Borrelli, F., Capasso, R., Severino, B., Fiorino, F., Aviello, G., De Rosa, G., ... Izzo, A. A. (2011). Inhibitory effects of bromelain, a cysteine protease derived from pineapple stem (Ananas comosus), on intestinal motility in mice. Neurogastronterology and Motility, 23, 745-751. http://dx.doi.org/10.1111/j.1365-2982.2011.01735.x

Bromelain Monograph. (2010). Alternative medicine review, 15(4), 361-368. Retrieved from http://www.chiro.org/alt_med_abstracts/ABSTRACTS/Bromelain_Monograph.pdf

Corzo, C. A., Waliszewski, K. N., \& Welti-Chanes, J. (2012). Pineapple fruit bromelain affinity to different protein substrates. Food Chemistry, 133(3), 5-9. http://dx.doi.org/10.1016/j.foodchem.2011.05.119

Emeruwa, A. C. (1982). Antibacterial substance from Carica papaya fruit extract. Journal of Natural Products, 45(2), 123-127.http://dx.doi.org/10.1021/np50020a002

Gudbjomsdottir, B., Suihko, M. L., Gustavsson, G., Thorkelsson, G., Salo, S., Sjoberg, A. M., ... Bredholt, S. (2004). The incidence of Listeria monocytogenes in meat, poultry and seafood plants in the Nordic countries. Food Microbiology, 21(2), 217-225. http://dx.doi.org/10.1016/S0740-0020(03)00012-1

Hale, L. P., Greer, P. K., Trinh, C. T., \& James, C. L. (2005). Proteinase activity and stability of natural bromelain $\begin{array}{llll}\text { preparations. } & \text { International } & \text { Immunopharmacology, } & 5(4),\end{array}$ http://dx.doi.org/10.1016/j.intimp.2004.12.007

Ketnawa, S., \& Rawdkuen, S. (2011). Application of bromelain extract for muscle foods tenderization. Food and Nutrition Sciences, 2, 393-401.http://dx.doi.org/10.4236/fns.2011.25055

Ketnawa, S., Rawdkuen, S., \& Chaiwut, P. (2010). Two phase partitioning and collagen hydrolysis of bromelain from pineapple peel Nang laecultivar. Biochemical Engineering Journal, 52(2-3), 205-211. http://dx.doi.org/10.1016/j.bej.2010.08.012

Lee, G. Y., Jang, H. I., Hwang, I. G., \& Rhee, M. S. (2009). Prevalence and classification of pathogenic Escherichia coli isolated form fresh beef, poultry, and pork in Korea. International Journal of Food Microbiology, 134(3), 196-200. http://dx.doi.org/10.1016/j.ijfoodmicro.2009.06.013

Llerena-Suster, C. R., Priolo, N. S., \& Morcelle, S. R. (2011). Sodium Tetrathionate effect on papain purification from different Carica papaya latex crude extracts. Preparative Biochemistry and Biotechnology, 41(2), 107-121. http://dx.doi.org/10.1080/10826068.2011.544230 
Lopez-Garcia, B., Hernandez, M., \& Segundao, B. S. (2006). Bromelain, a cysteine protease from pineapple (Ananas comosus), is an inhibitor of fungal plant pathogens. Letters in Aplied Microbiology, 55(1), 62-67. http://dx.doi.org/10.1111/j.1472-765X.2012.03258.x

Marsh, B. B., Woodham, P. R., \& Leet, N. G. (1966). Studies in meat tenderness III. The effects of cold shortening on meat tenderness. Journal of Food Science, 31, 450-459. http://dx.doi.org/10.1111/j.1365-2621.1966.tb00520.x

Ming, C. C., Awang, B., Duduku, K., \& Sing, H. (2002). Effects of Ionic and non-Ionic surfactants on papain activity. Borneo Science, 12, 71-77.

Nishimura, T., Hattori, A., \& Takahashi, K. (1995). Structural weakening of intramuscular connective tissue during conditioning of beef. Meat Science, 39, 127-133. http://dx.doi.org/10.1016/0309-1740(95)80014-X

Osato, J. A., Santiago, L. A., Remo, G. M., Cuadra, M. S., \& Mori, A. (1993). Antimicrobial and antioxidant activities of unripe papaya. Life Sciences, 53, 1383-1389. http://dx.doi.org/10.1016/0024-3205(93)90599-X

Prescott, L. M., Harley, J. P., \& Klein, D. A. (1990). Procaryotic cell structure and function. In K. Kane (Ed), Microbiology (pp. 48-51). Dubuque, IA: W. C. Brown Publishers.

Salampessy, J., Phillips, M, Senewera, S., \& Kailasapathy, K. (2006). Release of antimicrobial peptides through bromelain hydrolysis of leatherjacket (Meuchenia sp.) insoluble proteins. Food Chemistry, 120(2), 556-560.http://dx.doi.org/10.1016/j.foodchem.2009.10.054

Schirmer, T. (1998). General and specific porins from bacterial outer membranes. Journal of Structural Biology, 121(2), 101-109. http://dx.doi.org/10.1006/jsbi.1997.3946

Sofos, J. N., \& Geornaras, I. (2010). Overview of current meat hygiene and safety risks and summary of recent studies on biofilms, and control of Escherichia coli O157:H7 in non-intact, and Listeria monocytogenes in ready-to-eat, meat products. Meat Science, 86(1), 2-14. http://dx.doi.org/10.1016/j.meatsci.2010.04.015

Sparso, H. M., \&Moller, S. M. (2002).Proteolytic enzymes as antimicrobial agents and incorporation of hydrophobic additives into thermally compacted soy protein-based films. Research Thesis at Clemson University exchange with The Technical University of Denmark.

USDA-FSIS. (2005). US Department of Agriculture, Food Safety and Inspection Service, FSIS food recalls. Retrieved from http://www.fsis.usda.gov/Fsis_Recalls/Quantity_Recovered_by_Case_2005/index.asp 